Ethos : Jurnal Penelitian dan Pengabdian kepada Masyarakat, Vol 7, No.1, Januari 2019: 64-69

\title{
Pengenalan Khasiat Obat Tanaman Krisan Dan Pembuatan Teh Krisan Sebagai Minuman KeSEhatan
}

\author{
${ }^{1}$ Tia Setiawati, ${ }^{2}$ Annisa, ${ }^{3}$ Nurullia Fitriani dan ${ }^{4}$ Ichsan Nurul Bari \\ 1,2,3 Fakultas Matematika dan Ilmu Pengetahuan Alam Universitas Padjadjaran \\ ${ }^{4}$ Fakultas Pertanian Universitas Padjadjaran \\ Jl. Raya Bandung-Sumedang Km. 21, Sumedang 45363 \\ E-mail: ${ }^{1}$ tia@unpad.ac.id, ${ }^{2}$ annisa.annisa4@gmail.com, ${ }^{3}$ nurullia.fitriani@unpad.ac.id \\ ${ }^{4}$ ichsan@unpad.ac.id
}

\begin{abstract}
Abtract. Chrysanthemum plants are ornamental flower plants in the form of shrubs with other names seruni or golden flowers. Other than as an ornamental plant, this chrysanthemum has several health benefits including relieving the symptoms of influenza, headaches, and even cleaning the liver. The Community Service Program (PKM) was held in the Al Furqon madrasa, Ciwahang Village, Malangbong District, Garut Regency with women of Ciwahang Community Unit as participants on June 2018. The purpose of this community service program is to inform the public about the potential of Chrysanthemum as a medicinal plant for various diseases and how to make Chrysanthemum tea as a health drink. The method used in delivering counseling material through presentations with projector aids, while how to make the chrysanthemum tea was carried out in a demonstration involving several participants. The results of this activity were able to increase the knowledge of Ciwahang Community Unit women regarding Chrysanthemum plants, especially their properties as herbal medicine ingredients and community interest to cultivate Chrysanthemum plants in their yard.
\end{abstract}

Keywords : Chrysanthemum, medicinal plant, health drink

\begin{abstract}
Abstrak. Tanaman krisan merupakan tanaman bunga hias berupa perdu dengan sebutan lain seruni atau bunga emas. Selain sebagai tanaman hias, tanaman krisan ini memiliki beberapa manfaat dalam kesehatan di antaranya meredakan gejala influenza, nyeri kepala, bahkan dapat membersihkan liver. Kegiatan Pengabdian Kepada Masyarakat (PKM) ini dilaksanakan di madrasah Al Furqon, Kampung Ciwahang Desa Sukamanah, Kecamatan Malangbong, Kabupaten Garut dengan peserta ibu-ibu PKK pada tanggal bulan Juni 2018. Tujuan dari kegiatan Pengabdian Kepada Masyarakat ini adalah untuk memberi informasi kepada masyarakat mengenai potensi tanaman krisan sebagai tanaman obat berbagai penyakit serta cara pembuatan teh krisan sebagai minuman kesehatan. Metode yang digunakan dalam menyampaikan materi penyuluhan melalui presentasi dengan alat bantu proyektor, sedangkan pembuatan teh krisan dilakukan secara demo dengan melibatkan beberapa peserta. Hasil dari kegiatan ini mampu meningkatkan pengetahuan ibu-ibu mengenai tanaman krisan terutama khasiatnya sebagai bahan obat herbal serta ketertarikan masyarakat untuk membudidayakan tanaman krisan di pekarangannya. Kata kunci: krisan, tanaman obat, minuman kesehatan
\end{abstract}

\section{Pendahuluan}

Kampung Ciwahang merupakan sebuah kampung yang terletak di Desa
Sukamanah, Kecamatan Malangbong. Kampung Ciwahang terletak di sebelah 
utara Desa Malangbong dengan jarak sekitar satu kilometer dari pusat Kecamatan Malangbong. Desa Ciwahang merupakan salah satu desa di kecamatan Malangbong dengan tingkat perekonomian/ kesejahteraan dan sanitasi lingkungan masyarakatnya masih rendah sehingga rawan terkena penyakit. Sebagian besar matapencaharian masyarakat adalah sebagai petani baik menggarap lahan milik sendiri maupun menggarap lahan milik orang lain dengan sistem bagi hasil, bahkan menjadi buruh dengan upah harian menggarap lahan milik orang lain. Rendahnya tingkat kesejahteraan menjadikan masyarakat kesulitan mendapatkan obat-obat yang dijual di toko-toko obat/apotek yang untuk sebagian masyarakat masih dianggap mahal. Dengan demikian obat herbal yang berasal dari tanaman dapat dijadikan alternatif yang lebih ekonomis dan mudah diperoleh. Salah satu tanaman yang potensial dikembangkan dan belum banyak diketahui sebagai tanaman obat adalah krisan.

Krisan sudah lama dikenal menjadi tanaman penting floricultural dan tanaman hias, disisi lain krisan dimanfaatkan sebagai tanaman kuliner, obat, (etno) farmakologis, dan bahan biopestisida (Indah dkk., 2010; Teixeirada, 2003). Krisan dalam bidang kuliner dikemas dalam bentuk teh (Zulkarnain, 2009 dalam Hariyati dkk., 2016). Kandungan potensial pada daun dan bunga krisan memiliki prospek yang besar untuk diolah menjadi kudapan lainnya seperti permen, keripik, dan minuman instant (Wanita dkk., 2014). Listyani dan Widiawati (2013) juga menuturkan bahwa bunga, daun, bahkan batang krisan berpotensi sebagai zat pewarna alami pada kain sutera.
Pemanfaatan tanaman krisan sebagai tanaman obat belum banyak diketahui terutama masyarakat pedesaan. Hampir semua bagian tanaman krisan dapat dimanfaatkan untuk bahan obat. Bagian batang, daun, dan bunga tanaman krisan $(C$. morifolium Ramat) dapat digunakan untuk mengobati flu, mengatur tekanan darah, membantu detoksifikasi, meningkatkan sistem penglihatan, membantu menyembuhkan batuk, nyeri perut, sesak nafas dan sakit kepala akibat sinusitis (Lin dan Harnly, 2010; Rukmana dan Mulyana, 1997). Penilitian Zhang et al. (2009) mengungkapkan bahwa krisan dapat mengurangi kelemahan otot jantung, dan juga mengerahkan efek antiaritmia pada detak jantung yang mengalami gangguan ritme (terlalu keras) yang diinduksi oleh aconitine atau ischemia. Efek farmakologi lain dari krisan adalah sebagai penghambat dari aktivitas enzim HIV-1 integrase dan aldosa reduktase, sebagai antioksidan, antiradang, antimutagenik dan anti aktivitas alergi (Xie et al., 2009).

Kegiatan PKM ini bertujuan untuk meningkatkan pemahaman masyarakat khususnya ibu-ibu PKK mengenai khasiat tanaman krisan sebagai bahan obat dan pembuatan teh krisan sebagai minuman kesehatan serta meningkat minat masyarakat untuk menanam krisan sebagai apotek hidup yang juga menambah nilai estetika.

Kegiatan PKM ini sangat bermanfaat agar masyarakat kampung Ciwahang mengetahui pemanfaatan tanaman krisan sebagai obat herbal untuk berbagai macam penyakit yang mudah didapatkan dan dibudidayakan di pekarangan rumah. Selain itu, dengan mengetahui pembuatan teh dari bunga 
krisan kering sebagai minuman kesehatan, masyarakat diharapkan dapat mengembangkannya sebagai produk yang mempunyai nilai jual sehingga dapat membantu meningkatkan kesejahteraan/perekonomian

\section{Metode Penelitian}

Kegiatan PKM ini terdiri dari dua tahap kegiatan yaitu penyuluhan dan pembuatan teh krisan. Penyuluhan dilakukan kepada ibu-ibu PKK dengan pertimbangan bahwa mereka memiliki peranan lebih dalam menerapkan dan mengembangan hasil penyuluhan selanjutnya. Materi penyuluhan disampaikan melalui presentasi menggunakan media proyektor secara langsung kepada peserta. Materi dalam slide dikemas secara menarik dengan gambar dan video agar mudah dipahami oleh peserta. Kegiatan penyuluhan diarahkan pada peningkatan pengetahuan serta sikap masyarakat dalam pemanfaatan tanaman krisan sebagai obat alternatif untuk mengatasi berbagai penyakit terutama penyakit ringan yang sering terjadi di masyarakat seperti flu, demam, batuk dan lain sebagainya.

Pembuatan teh krisan sebagai minuman kesehatan dilakukan secara demonstrasi dengan melibatkan beberapa peserta dan hasilnya langsung dinikmati (dicicipi) oleh semua peserta. Pembuatan teh krisan dilakukan secara sederhana dengan cara merebus bunga kering krisan dan penambahan madu atau gula sebagai pemanis/penambah rasa dan untuk mengurangi rasa sepet.

Setelah pemaparan materi, dilakukan diskusi dan peserta diberi kesempatan untuk bertanya sehingga materi yang disampaikan dapat dipahami secara menyeluruh.

\section{Hasil dan Pembahasan}

Berdasarkan permasalahan utama yaitu rentannya masyarakat terkena penyakit akibat sanitasi lingkungan yang buruk di kampung Ciwahang dan rendahnya kesejahteraan masyarakat setempat sehingga dirasakan sangat penting untuk mencari obat alternatif yang lebih ekonomis dan mudah diperoleh. Pengenalan krisan sebagai tanaman obat kepada masyarakat kampung Ciwahang melalui kegiatan penyuluhan menambah informasi baru yang bermanfaat dalam meningkatkan kesehatan masyarakat.

Bagian tanaman krisan yang sering dimanfaatkan sebagai obat adalah bunga dan daun. Pengolahan bagian tanaman krisan yang akan dijadikan sebagai bahan obat sangat mudah. Sebagai contoh untuk mengobati sakit batuk diperlukan rebusan 1 mangkuk daun dan bunga krisan kering dalam 2 gelas air, air rebusan tadi diminum dengan dosis anjuran setiap jam meminum 1/2 mangkuk (dewasa), 1/4 mangkuk (anak umur 7-12 tahun), 2 sendok makan (anak umur 2-6 tahun), atau satu sendok teh (bayi). Demikian juga dengan nyeri perut karena angin yang berlebihan dalam perut dan usus dapat diobati dengan daun krisan yang dirajang atau ditumbuk, kemudian dicampur dengan minyak kelapa dan digosokan pada perut dengan menggunakan kain kebat, lalu dibiarkan selama semalam atau minimal 4 jam (Anonim, 2013).

Pada kegiatan demo pembuatan teh krisan, beberapa peserta diikutsertakan dan mencoba membuat teh krisan sendiri. Yang digunakan untuk membuat teh adalah bunga krisan yang telah dikeringkan, namun pada saat kegiatan ini bunga kering yang 
digunakan adalah bunga kering siap rebus yang banyak diperjualbelikan. Namun demikian kepada peserta disampaikan pula proses pengeringan bunga krisan dapat dilakukan sendiri dengan sangat mudah, yaitu dengan terlebih dahulu dicuci dengan air mengalir, lalu dikukus untuk pelayuan, kemudian dikeringkan di bawah sinar matahari langsung atau dengan oven suhu $60^{\circ} \mathrm{C}$ selama 24 jam sampai bunga kering. Selain bunga, teh krisan dapat pula dibuat menggunakan daun krisan. (Anonim, 2018).

Proses pembuatan the krisan sangat mudah dilakukan dengan peralatan sederhana yaitu dengan merebus 50 gram bunga kering dengan $500 \mathrm{~mL}$ air dan didihkan hingga setengahnya Untuk menambah cita rasa teh dan menghilangkan rasa sepet dapat ditambahkan gula/madu serta jeruk nipis atau jahe secukupnya. Namun demikian, teh krisan memiliki efek samping bagi seseorang yang sensitive seperti alergi, ruam ataupun masalah perut (https://www.amazine.co/38396/caramembuat-teh-krisan-chrysanthemumtea-efek-sampingnya/)

Kepada peserta disampaikan pula bahwa bunga krisan kering memiliki nilai ekonomi tinggi, dengan harga mencapai hingga Rp. 100.000/100 gram, sehingga membuka peluang bisnis yang menjanjikan bagi masyarakat yang tertarik mengembangkannya. Kondisi lahan di kampung Ciwahang memiliki tingkat kesuburan yang baik sehingga sangat mendukung untuk membudidayakan tanaman krisan.

Selain itu dengan pembuatan yang mudah, teh krisan punya banyak khasiat karena dapat menjaga sistem kekebalan tubuh, mengatasi berbagai penyakit yang disebabkan infeksi bakteri, menurunkan suhu tubuh, menjaga kesehatan kulit, mengatasi aterosklerosis, menurukan kolesterol, meningkatkan fungsi otak, meredakan batuk, sakit kepala, sakit gigi ringan dlsb (https://manfaat.co.id/manfaat-tehbunga-krisan).

Selama kegiatan berlangsung, respon peserta sangat baik dan antusias memperhatikan pemaparan materi penyuluhan. Pada sesi diskusi peserta banyak bertanya dan memperlihatkan ketertarikannya untuk menanam tanaman krisan di pekarangan rumahnya sehingga jika sewaktu-waktu diperlukan mudah diperoleh. Kegiatan ini telah meningkatkan pemahaman masyarakat terhadap manfaat lain tanaman krisan di samping sebagai tanaman hias. Masyarakat mendapatkan manfaat berupa informasi dan pengalaman baru dalam mengolah bunga krisan menjadi minuman kesehatan berupa teh yang mudah dibuat dengan banyak khasiat. Berikut beberapa dokumentasi selama kegiatan berlangsung dapat dilihat pada Gambar 1. berikut :
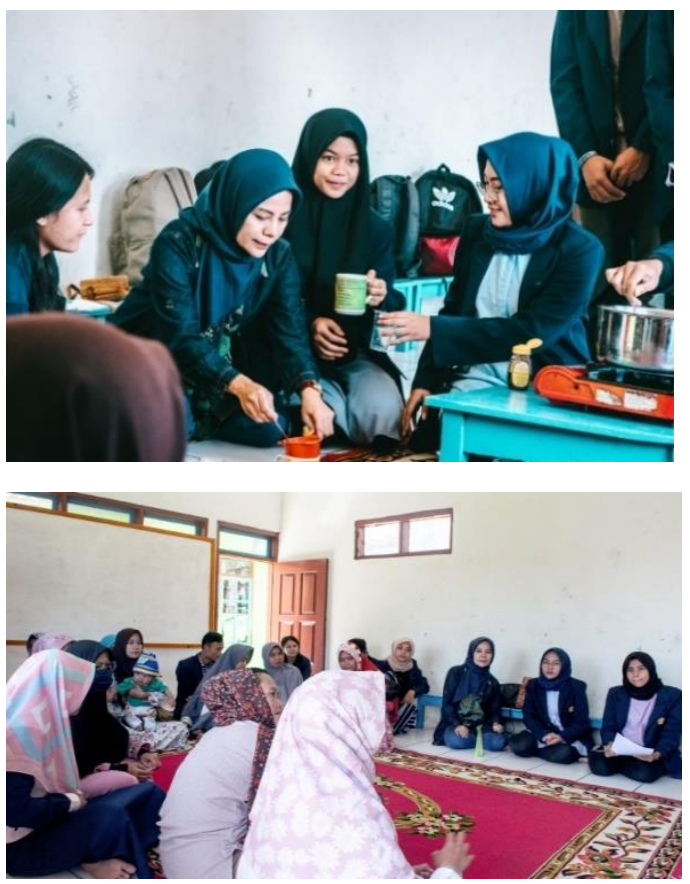

https://doi.org/10.29313/ethos.v7i1.4133 

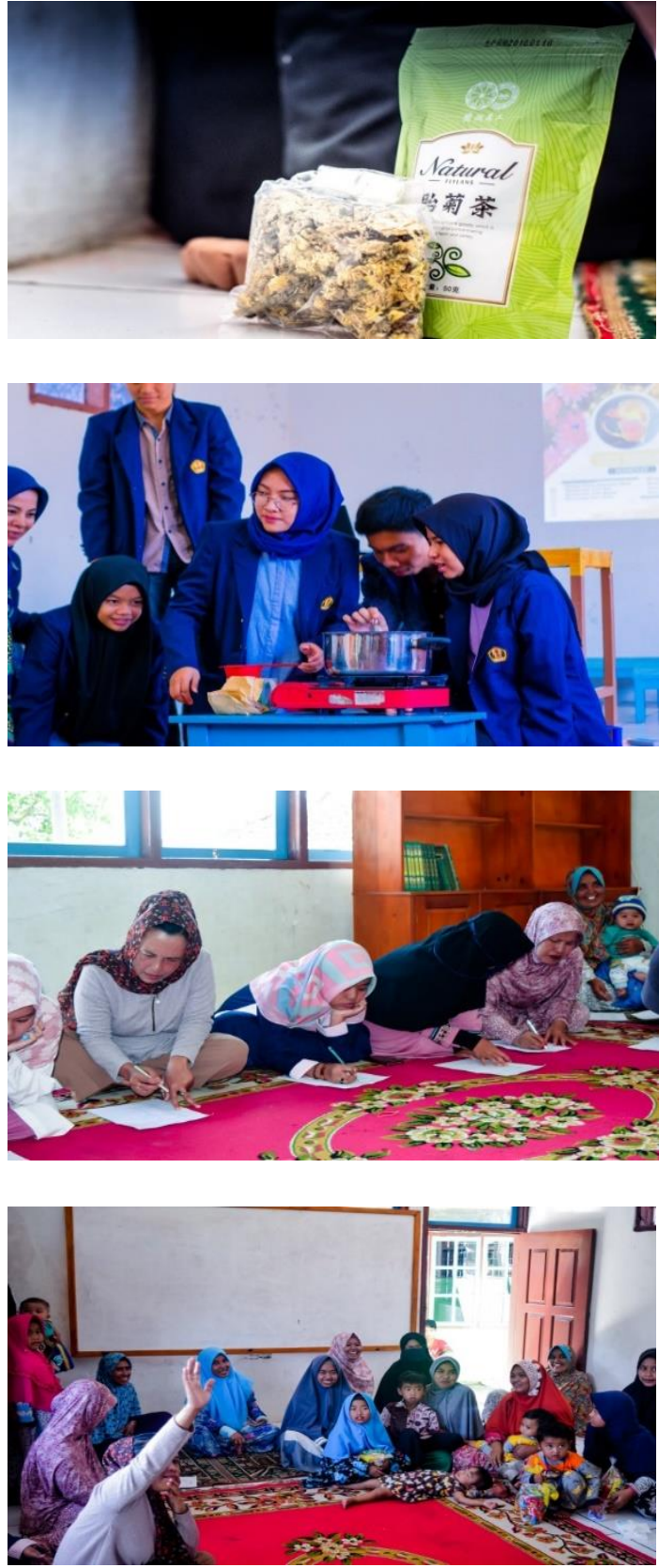

Gambar 1. Kegiatan penyuluhan mengenai manfaat krisan sebagai tanaman obat dan demo pembuatan teh krisan

\section{Kesimpulan dan Saran}

\section{Kesimpulan}

Melalui kegiatan pengabdian kepada masyarakat berbasis pemanfaatan obat herbal sebagai alternatif dalam pengobatan beberapa penyakit yang sering timbul di masyarakat dengan tingkat sanitasi lingkungan rendah, pemahaman masyarakat desa Ciwahang mengenai penggunaan tanaman krisan sebagai tanaman obat mengalami peningkatan setelah mengikuti program penyuluhan ini.

\section{Saran}

Saran yang dapat disampaikan berdasarkan hasil kegiatan PKM ini adalah para kader PKK diharapkan dapat memanfaatkan pekarangan rumahnya untuk membangun apotek hidup dengan penanaman tanaman obat keluarga (TOGA) termasuk tanaman krisan. Selain itu berbekal pengetahuan yang diperoleh dari penyuluhan ini diharapkan para kader PKK memiliki inovasi dalam pengembangan dan pengolahan bahan tanaman obat khususnya teh krisan sehingga dapat dijadikan sebagai usaha rumahan untuk menambah penghasilan keluarga.

\section{Ucapan Terimakasih}

Ucapan terimakasih yang sebesar-besarnya disampaikan kepada Rektor Universitas Padjadjaran, DRPMI Unpad, dan Departemen Biologi FMIPA Unpad . Kegiatan Pengabdian kepada Masyarakat (PPM) ini dapat terselenggara atas dana Hibah Internal Unpad.

\section{Daftar Pustaka}

Anonim. 2018. https://unsurtani.com/2018/03/resepmembuat-teh-daun-bunga-krisan [diakses 13 Oktober 2018]

Anonim 2013. http://manfaat33.blogspot.com/2013 /10/manfaat-khasiat-daun-dan- 
bunga-krisan.html [diakses 13 Oktober 2018]

https://www.amazine.co/38396/cara-

membuat-teh-krisan-

chrysanthemum-tea-efek-

sampingnya/ [diakses 13 Oktober 2018]

https://manfaat.co.id/manfaat-tehbunga-krisan [diakses 13 Oktober 2018]

Indah, B., Hartal dan Misnawati. 2010.

Efektifitas Thricoderma sp. dan Gliocladium sp. dalam pengendalian layu fusarium pada tanaman krisan, Jurnal Ilmu Pertanian Indonesia, Vol. 12, No. 1, pp. 7-12

Hariyati, M., Bachtiar, I., dan Sedijani, P. 2016. Induksi kalus tanaman krisan (Chrysanthemum morifolium) dengan pemberian benzil amino purin (BAP) dan Dichlorofenoksi acetil acid (2,4 D), Jurnal Penelitian Pendidikan IPA, Vol. 2, No.1.

Lin, L.Z. and Harnly, J.M. 2010. Identification of the phenolic components of chrysanthemum flower (Chrysanthemum morifolium Ramat), Food Chemistry, Vol. 120, pp. 319-326.

Listyani, N.G. dan Widiawati, D. (2013). Eksplorasi bunga krisan (Chrysanthemum) sebagai zat pewarna alami pada kain sutera untuk produk fashion. ITB Undergraduate, Journal Visual Art and Design, Vol. 2, No.1.
Rukmana, H.R. dan Mulyana, A.E. (1997). "Krisan". Yogyakarta: Kanisius.

Teixeirada, S.J.A. (2003). Chrysanthemum: advance in tissue culture, cryopreservation, postharvest technology, genetics and transgenic biotechnology, Journal Biotechnology Advances. Vol. 21, pp. 715-766.

Wanita, Y.P, Setyono, B., dan Agriawati, D.P. (2014). Krisan (Chrysanthemum indicum L.) organic sebagai bahan baku aneka pangan olahan. Prosiding Seminar Nasional Pertanian Organik. pp. 445450

Xie, Y.Y., Yuan, Yang, J.Y., Wang, L.H., and Wu, C.F. (2009). Cytotoxic Activity of Flavonoids from The Flowers of Chrysanthemum morifolium on Human Colon Cancer Colon 205 Cells. Journal of Asian Natural Products Research, Vol.11, No. 9, pp. 771-778.

Zhang, W., Ye, Z.G., Cui, J., Qiu, S.F., $\mathrm{Xu}$, W.H., Wang, H.P., Qian, L.B., Jiang, H.B., and Xia, Q. (2009). Antiarrhythmic effect of ethyl acetate extract from Chrysanthemum Morifolium Ramat on rats. International Journal Medical Sciences, Vol. 38, pp. 377-382. 